\title{
ARCHAEOLOGICAL EXCAVATION OF THE HABAN COLONY SITE AT SÁROSPATAK
}

\author{
István RINGER \\ Kazinczy Ferenc Museum \\ Dózsa György u. 11, 3980 Sátoraljaújhely, Hungary \\ E-mail: ringeri@kazinczymuzeum.hu
}

\begin{abstract}
This article reports on the first results of the archaeological excavation of the Haban colony site in Sárospatak begun in 2010. It describes the circumstances of the origin of the Anabaptist colony that can be located precisely from topographical data, and briefly outlines the history of the Haban colony in Sárospatak. In the first two years of the exploration on the basis of a research programme, the archaeological exploration of the house at No. 8 Kövi Sándor utca began; the main aim was to clarify the stratigraphy of the place with test trenches. In the course of the work an unexpected quantity of archaeological finds that can be linked to Anabaptist ceramics came to light. Especially important are the finds that can be linked to the firing kiln: the bricks of the kiln, the firing slabs, saggars, fragments of the crucibles used to melt the glazes. The lead-glazed ceramics of the Anabaptists are little known in research on Early Modern ceramics. The lead-glazed ceramics unearthed from the site of the Sárospatak colony differ strikingly from Early Modern pottery of the region. It will be the task of further research to decide whether the Habans produced lead-glazed ceramics exclusively for their own needs or also for the market.

Keywords: Sárospatak Haban colony, György Rákóczi I, archaeological exploration, pottery kiln, Haban lead-glazed ceramics
\end{abstract}

János Román was the first person to collect archival data on the Habans of Sárospatak that he published in a separate short monograph (Román 1959). His research was later supplemented by Mihály Détshy from further archival sources - mainly letters - containing information on the circumstances of the settlement, and on the internal life of the colony.

Anabaptist craftsmen were already active in Sárospatak before 1645, the year when the larger community settled there. In the 1630 s, correspondence relevant to Sárospatak mentions mainly carpenters and millers, but there is also a reference to an Anabaptist healing barber and gardeners (DÉTSHY 1972: 10-11, note 12). Talks on the settlement of Anabaptists in Sárospatak began in 1643. During his military campaign in early August 1645, György Rákóczi I visited Haban communities in north-west Hungary, Szobotist (Sobotište, Slovakia) and Csejte (Čachtice, Schächtitz, Slovakia); it was probably then that 
he persuaded some of the communities to move to Sárospatak. One of the sites suitable for their settlement was in the south of the town, in Alsó Hóstát, while the other was in the eastern part known as Héce in the northern, Felsö Hóstát half of the town.

We know from the urbarium (rent-roll) for 1650 and 1657 that among the Anabaptists settled in the town there were 50 adult male workers, 13 of whom were craftsmen, most of them with their journeymen, working in 12 different trades. The distribution by trade was: 1 boot maker with 3 journeymen, 1 tanner, 1 cloth-maker with 2 journeymen, 1 blacksmith with 3 journeymen, 1 wheelwright, 1 cooper, 1 cutler with 6 journeymen, 2 millers, 1 tailor, 1 potter with 4 journeymen, 2 weavers, 1 barber with 2 journeymen. Sixteen persons - chief steward, gatekeeper, cruiser, chaff cutter, coachman, labourer, gardener, brewer, three bakers (females), two priests and a schoolmaster - carried out the settlement's household tasks. According to the memoirs of Conrad Jacob Hildebrandt, who passed through Sárospatak in 1656, the Anabaptist community numbered around 200 souls (DÉTSHY 1972: 133; note 70). The members of the community were led by György Stilmar (MOL U et C fasc. 41. No 3). The Habans in Sárospatak were engaged not only in industry but also in agriculture: the agricultural branch of the colony was in Kispatak. Although we know only the deed of gift dated 1647 for the properties placed at the disposal of the Anabaptists - their original agreement with the estate has not survived - the urbarium of 1650 set out their obligations in detail.

The period from 1645 to the death of Zsuzsanna Lorántffy in 1660 in the history of the Haban colony in Sárospatak can be regarded as peaceful and secure. With the appearance of the Jesuits in Sárospatak in 1663, the Catholicisation of the Anabaptists began on the order of Zsófia Báthory, Ilona Zrínyi and Ferenc Rákóczi I. The Jesuit Johannes Grueber played a key role in this between 1666 and 1680. The process of Catholicisation led first to the disintegration of the economic community and later of the entire settlement. The last entry concerning the Habans in the Historia Domus of the Jesuits in Sárospatak is dated 1673. According to the urbarium for 1676, due to the destruction caused by war, only 18 persons remained in the Anabaptist colony. By then Ferenc Rákóczi I had reduced their previous tax of 100 florins by half, in exchange for which the Habans gave him their orchard beside the Bodrog River, their brewery and drying house. Probably some of the residents of the Haban court moved elsewhere, the others gradually assimilated into the population of Sárospatak, mainly through the intermarriages that began with townspeople and tradesmen.

An important consideration in settling the Habans in Sárospatak was that in return for the concessions offered, the prince had access at favourable prices to products to meet the needs of his own court and estates, with which the local tradesmen could not compete. And the largest group of tradesmen among the Sárospatak Habans, the cutlers, not only had no local competitors but perhaps not even anywhere in the country. ${ }^{1}$ Under the agreement between György Rákóczi I and the Habans settled in Sárospatak, they had to make their products available to the state for half of the market price, as recorded in the urbarium of 1650 and transcribed in 1657 (MOL $U$ et $\mathrm{C}$ fasc. 41. No. 3).

${ }^{1}$ According to the perhaps slightly exaggerated description given by Conrad Jacob Hildebrandt, the “community has a large income from knives, because they supply the whole of Hungary.” Cited by DÉTSHY 1972: 134. 
Perhaps the estate also traded in the products it bought from the Habans at half price. This seems to be supported by the fact that in an inventory dated 12 November 1685,105 white ceramic plates and three similar bowls made by Anabaptists were recorded in the bastion on the market side of the outer castle (AFR fasc. 33. No. 366).

The site of the Haban colony can be precisely localised with the help of historical and topographical data; it was in the northern part of Sárospatak known as Héce, in an area bordered by today’s Dobó Ferenc utca, Fazekas sor, and Kövi Sándor utca. A number of elements linked to the Habans can still be found here. In the late $1960 \mathrm{~s}$, a house at No. 5 Dobó Ferenc utca was demolished; because of its unusual form and layout and also its wooden-frame structure unique in the town, it was generally known as the "Haban house" (ROMÁn 1959: 12). Excavation of the Haban colony site began in the frame of a scientifically planned research. The topic is important because the site in Sárospatak is the only Haban colony site on the territory of present-day Hungary. The archaeological research began in the garden of the house at No. 8 Kövi Sándor utca in the autumn of 2010. This site is the centre of the clearly circumscribable former Haban settlement; it can be identified as the large, vacant area on the Römisch map. A horde of coins weighing a total of 2,550 grams was found when drains were dug on the site in 1974. On the basis of the 1678 stamp on the coins, it seems probable that they were buried at the time of the disintegration of the settlement. ${ }^{2}$ Before beginning the archaeological exploration, a magnetometric survey was made of the entire $750 \mathrm{~m}^{2}$ area. We staked out a grid of 5 metres $\times 5$ metres over the entire site divided into two research zones (A: western part of the site; B: eastern part) and numbered the units accordingly. In 2010 and again in 2012, the research concentrated on the western half of the site. Between the 15-20 cm upper stratum of humus containing recent finds and the prehistoric stratum, a grey stratum of loose structure, containing rich Early Modern age finds, mixed with grains of mortar and bricks, represents the $17^{\text {th }}$ century horizon. Two coins were also found here: a silver six groat coin issued by the Polish king John II Casimir (1648-1668), and a 15 kreuzer struck by Karl II von Liechtenstein (1664-1695) Bishop of Olmütz. The finds of ceramics and stove tiles from this stratum - the great majority lead-glazed pottery ware, a few fragments of tin-glazed faience vessels - confirm the connection between the stratum and the Haban colony site. A number of modern digging incursions in the area have disturbed the $17^{\text {th }}$ century stratum.

In units $\mathrm{A} / \mathrm{II}$ and $\mathrm{A} / \mathrm{VI}$, we documented remains of the foundation wall of a large building. In 2012, in unit A/V opened to the north of A/VI, we excavated a further 3 metre stretch of the northern wall of the building. (We were unable to continue this excavation because the layout extended to the west and the south beyond the site of the present excavation.) Here we were able to document on a larger surface a layer of yellowish clay trodden hard, indicating the floor level of the building. On this level, in front of the building's eastern wall, $80 \mathrm{~cm}$ to the east we excavated a post hole $10 \mathrm{~cm}$ in diameter and $40 \mathrm{~cm}$ deep, filled with loose, crumbly soil; we found at the edge an in situ iron hoop and an iron attachment. Beside the NE corner of the building's foundation - where the magnetometric

\footnotetext{
${ }^{2}$ MNM Adattár XXVII. 269/1978. The find of coins comprised 861 items.
} 


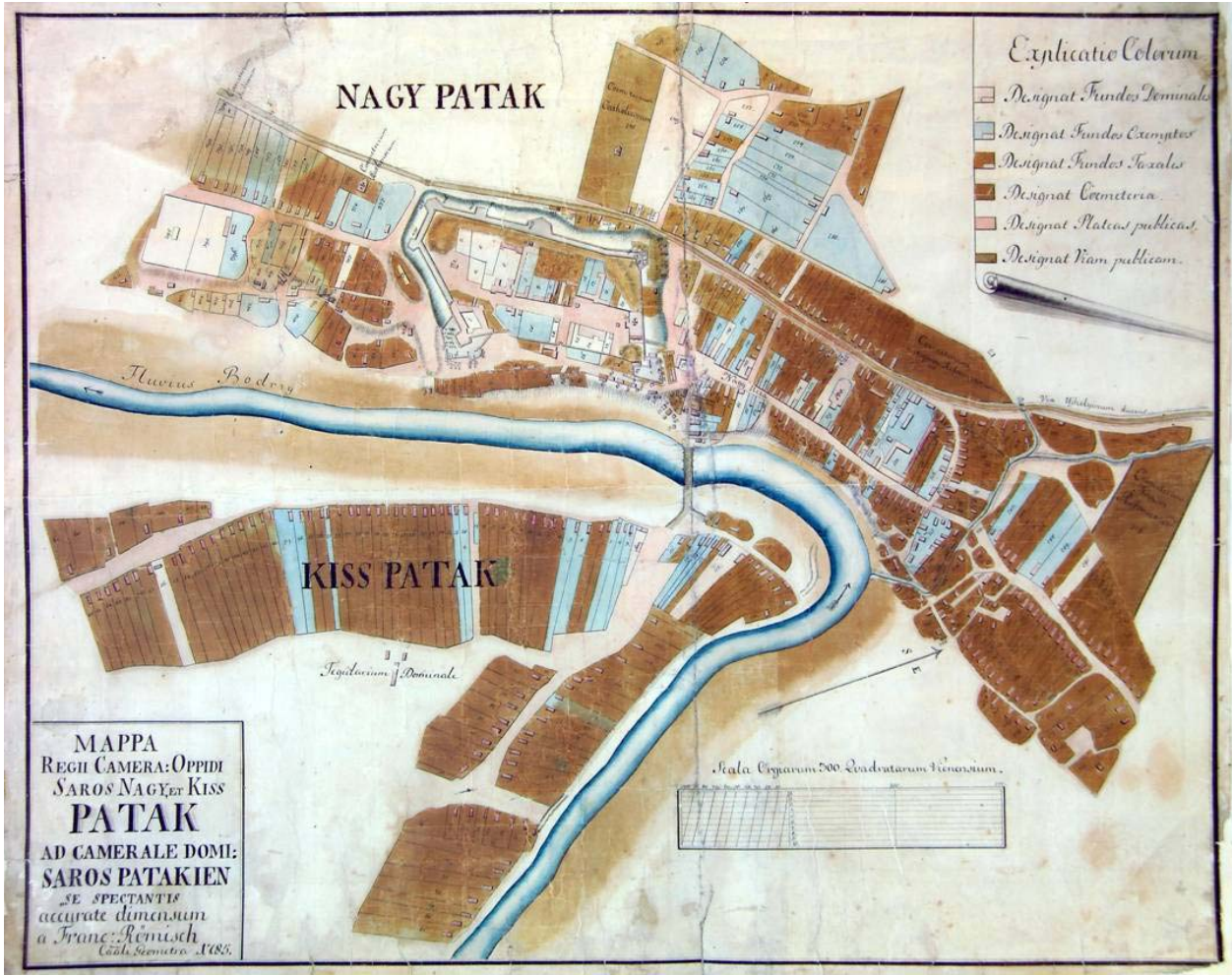

Site of the Sárospatak Haban colony (Curia Anabaptistarum) marked on the map of the town made by Ferenc Römisch in 1785

survey had indicated an anomaly that could be clearly interpreted - at a relative depth of $40 \mathrm{~cm}$, over a surface of 2 metres $\times 2$ metres we observed a concentration of finds consisting of thoroughly fired, plastered pieces, brick fragments and fragments of firing slabs. In the south-west corner of the neighbouring unit, to the north of this opened in 2012 (unit $2012 / \mathrm{II}$ ) at a relative depth of $40-45 \mathrm{~cm}$, in a clayey, stony surface of $1.5 \mathrm{~m}^{2}$, we found a concentration of finds $30 \mathrm{~cm}$ thick, containing very fragmented ceramic material and a small quantity of firing slabs and burnt brick. The examination following restoration of the ceramic objects found here showed that they were beyond doubt exclusively broken pieces of vessels thrown out as kiln waste after firing. The pieces in the find comprising fragments of around 50 different vessels were without exception vessels for the storage of liquids: mainly various types of jugs. In almost all cases one or more thick, lengthwise cracks could be seen on the handles of the jugs, showing that these pieces had been rejected after the first, unsuccessful firing and so were not glazed. The connected material found at the same level in the two neighbouring units can be interpreted as waste strata, indicating a potter's workshop. Fragments of firing slabs and pieces of strongly burnt - in cases vitrified - kiln bricks occurred sporadically at several points of unit 2012/II. It can be determined from the results of the small area excavated (the area explored was only 
$145 \mathrm{~m}^{2}$ ) that the potter's workshop was almost certainly located on top of the hill; it must have stood among the other workshops and buildings of the colony site. The indirect pieces of evidence that can be linked to the former Haban pottery kiln, that were found in all our grid units, unequivocally increased in number in the area in front of the north-east corner of the building remains described above. We therefore think that the in situ remains of the pottery kiln are most likely to be located to the west or north of that point (in two different neighbouring plots).

The find material comprises fragments of ceramics (60\%), stove tiles (30\%), and $10 \%$ other silicate and metal finds (bricks, firing slabs, glass fragments, unique objects, pieces of iron, etc.). Very few pieces of metal were found: a bronze metal book corner, a hand drill, a pair of pincers and three knives merit special mention. For reasons of space, from among the varied ceramics and stove tile finds (Fig. 8) I shall deal in the present article only with the little known lead-glazed vessels decorated with trailing, and with the closed group of items that can be interpreted as kiln waste.

The Haban potters worked in a workshop that they built together; their tools and the materials needed for their craft were owned collectively. We can draw conclusions regarding the way the work was organised mainly from the regulations governing potters and from information in contemporary chronicles. Production was based on a division of labour that extended to even the tiniest work phases. Ideally, a separate potter was responsible for the clay mixture and the firing; preparing the moulds and the pattern sheets, moulding or throwing, assembling the glazes, glazing and decoration were separate jobs (BunTA 1973: 28-29).

The handbook on the craft of pottery written by Cipriano Piccolpasso gives us information on the structure of the "ideal" pottery workshop in the Renaissance period. The pottery kiln he describes had an internal volume of 180 cubic feet, that is, slightly more than five cubic metres. According to calculations based on a kiln of this size, two potters engaged in shaping could produce sufficient pots for two firings a month. Decorating the vessels was naturally a much more time-consuming work phase than throwing and moulding. But since parts of the ceramics were undecorated, traditional pottery ware, there could not have been a big disproportion between the two work stages. In general, two potters working at throwing could provide continuous work for two or three vessel decorators. The pottery workshops of Haban colonies, where a number of potters worked, probably operated in a similar system. We know from surviving sources on the activity of the Habans in Alvinc that there was a leading supervisor above the potters, called "Vorgestelter Hafnermeister" in the chronicles; it was his task to organise the work processes and allocate the work (BUNTA 1973: 28).

Although their products were characterised by a high degree of variety in form and decoration up to the mid- $17^{\text {th }}$ century, the Anabaptists clung to certain characteristic types for decades. The precursors of the typical, conservative forms can be sought not only in Italian ceramics but also in German and Dutch pewter, wood and glass vessels. The insistence on traditions is related to their way of life in closed communities (RADVÁNYI - RÉTI 2011: 27). The Haban potters who settled in Sárospatak had a well established craft practice, and that practice was based on technological procedures that represented the highest degree of development in Central Europe at that time. 
Most of the raw material for pottery in the Zemplén region came from the valleys of the Bodrog River and the tributaries. The sources of clay, which is of primary importance for pottery, are found within the area of the town. A thick stratum of good quality clay with very little gravel or vegetable debris lies close to the surface (RomÁn 1965: 26). The clay, originating from erosion of volcanic rocks, is dark brown in colour and poor in lime; after firing, it acquires a bright brick red colour. It is easy to recognise fragments of dishes fired from this clay, from their graininess and colour. The lead-glazed ceramics and stove tile finds from the Haban settlement were almost exclusively made from this kind of clay. We frequently come across the statement in the literature that the Habans used different kinds of clay for flatware (this was the so-called tálföld (plateearth, flat clay), and for hollow ware (KATONA 1974). The larger group of faience fragments from Sárospatak - with one exception all the vessels covered with white tin glaze inside and out, and all the fragments of vessels with an underglaze of turquoise or manganese purple without exception - belonged to the pots fired to a yellow or dirty white colour. However, in the case of pots covered with a blue glaze, half were fired to a brick red colour and the other half to a light colour. No correlation can be found in the material excavated to date between the type of pot and the colour of its body.

Apart from the material used for the body of the vessels, two important earth colorants, white and red, can also be found in the area around Sárospatak. Records from the late $19^{\text {th }}$ century show that the thinner kind of white was taken from the colorant quarry on the side of Megyer Hill to the north of the town. Slip made from this became chalk white after the first firing; it could also be found on the fragments in this shade (Román 1955: 5).

The lead-glazed vessels made in the Haban settlement in Sárospatak are generally characterised by the use of a white engobe beneath the glaze. On the ceramics covered with a colourless lead glaze inside, it can be observed that the same white engobe was used for the trailed decorations. Traces indicating the use of red engobe could not be found on the fragments excavated so far.

The jugs, tankards, plain bowls, etc. - were made by the potters on a wheel. According to the evidence of the image that had survived on a jug bearing the date 1593, probably made at Tavíkovice in Moravia, the Haban potters used a block-wheel (PAJER 2011: 11; 1c. illustration). The same image of a wheel appears on the potter's guild panel from Nagylévárd dated 1732, which seems to prove that this wheel type was used throughout the entire history of Haban pottery. In this type of wheel, a rotating part that contained both the turntable and the wheel base was placed on a horizontal axis. The throwing technique used by the Haban potters was regarded as very virtuoso: making large bellied vessels with a narrow mouth and thin walls required a very high degree of skill. The larger bodied vessels found among the kiln waste in the Sárospatak Haban colony typically had a wall thickness of only 2-3 mm.

The tool used during throwing was a wooden knife that served to give vessels their final form. The perpendicular or spirally twisted fluting that can often be observed on tall vessels and incised line decorations were made with the help of the wooden knife. While there are numerous examples of fluting among our finds, the use of incised line decorations could be observed only on cooking pots with legs. The rectangular forms, hand basins, salt cellars, inkpots were fitted together from slabs. There is only one object made in this way among our finds, a fragment of a rectangular lid. 
An important group of ceramic objects produced by the Haban potters was made by moulding. The handles of cups or small bowls were made by pressing the clay into moulds; an example with a manganese purple faience glaze and one covered with a green lead glaze are known from the Haban settlement in Sárospatak. An intact mould used for making such handles, with the date 1612 incised on the reverse side was found in 2005 from a Haban colony site in Vacenovice, Moravia (PAJER 2007: 246; Fig. 33). An especially high degree of technical skill was needed to make perforated bowls of Italian origin, known as traforata type, mentioned by Piccolpasso as a basket shape (forma di canestrelle) (Ridovics 2008: 93). An entry in the inventory made in the Sárospatak castle on 1 May 1639, describing the item as "White-glazed openwork cup with foot made by New Christians" may refer to the perforated bowls on stand used to serve fruit or cakes (DÉTSHY 1972: 125). The inventory made in Rohonc in 1635, listing "a basket made by New Christians of clay”, may also refer to a perforated bowl (RIDOvics 2008: 93). Perforated bowls occur more frequently in the early period, but only sporadically from the turn of the $17^{\text {th }}$ to the $18^{\text {th }}$ century. The most common of their patterns formed with a template was a rich pattern composed of curves and tendrils evoking heraldic lilies (RADVÁNYI - RÉTI 2011: 28). The procedure of shaping and decorating with a perforated pattern clearly reflecting Italian influence is unknown in Transylvanian Haban ceramics (BunTA 1973: 65). We were not able to identify fragments belonging to perforated bowls among the ceramics material excavated to date in the Sárospatak settlement, but the fragment of a template is proof that the Haban potters in Sárospatak made such pieces too. Triangles and curved tendrils can be observed on the fragment of the finely worked mould made of clay fired to a yellow colour and $23 \mathrm{~cm}$ in diameter. Fragments of the moulds used to make perforated bowls are known from the Moravian finds from Vacenovice (PAJER 2006: 123; Fig. 4).

The Habans in Sárospatak also used moulds to make stove tiles, also of fired clay. Two fragments of tile moulds were unearthed on our site, fired to a yellow colour like the mould for perforated bowls, of very finely worked, solid material.

There is no evidence among the surviving ceramics and stove tiles that the Haban potters used sprigs, applied decorations or stamped motifs on their products. For this reason the stamp found, $3 \mathrm{~cm}$ long, made of clay burnt white with a slightly different pattern on either end suitable for stamping, is such a special find. Despite the fact that as yet there is no evidence of the use of a stamp in the Moravian settlements either, a potter's tool of similar size to that from Sárospatak, although for use at only one end, is known from Vacenovice. ${ }^{3}$

After shaping, the pots and tiles were left to dry, then came the process of applying the engobe that was generally used on the lead-glazed ceramics and stove tiles from our site. The most critical phase of the work was the firing that comprised the first firing, followed by the second firing after glazing. The archaeological research carried out so far has been able to provide only indirect evidence of the location of the potters' workshop operating in the Haban settlement in Sárospatak and the kiln that was an integral part of it: the in situ remains of the kiln have not yet come to light. János Román localised the potter's workshop to the end of today's Fazekas sor (= potters' row) nearest the town and specifi-

3 Unpublished, oral communication by Jiří Pajer. 
cally to the area below the hill (Román 1959: 13). The workshop debris and other types of finds that can be associated with a pottery kiln brought to light during the archaeological excavation show that the pottery kiln must have stood in the central area of the colony site; the workshop was presumably nearby, perhaps within the workshop building itself, at the top of the hill. The Haban potters probably used a kiln type of Italian origin described by Piccolpasso. The first pottery kiln that could definitely be linked to the Habans was excavated by Heřman Landsfeld in the village of Ostrožská Nová Ves (Czechoslovakia) in May 1942. The remains of two smaller, earlier kilns were also unearthed in the course of the excavation, but they were not documented in such detail as the later, larger kiln. A reliable description can be given of the latter on the basis of the notes made by the archaeologist Jiři Pajer, the site map and the photographic documentation. The rectangular kiln measured $300 \times 400 \mathrm{~cm}$ on the outside and the rounded rectangular interior $200 \times 380 \mathrm{~cm}$. On the front side of the kiln, beneath the opening, there was a vaulted brick pit. It must have been easier to heat the kiln by stepping into the pit and the ashes could also be cleaned out of the heating channels from here. The firewood cut into very thin pieces was placed in the three vaulted channels formed in the interior of the kiln. The heating channels were covered with clay slabs - firing slabs- that transmitted the heat into the firing chamber. The glazes were melted in the firing chamber after first being ground into small pieces and placed in crucibles. Both pots and stove tiles were placed on firing slabs to prevent direct contact with the fire and so avoid smudges on the surface of the faience vessels. The foundation of the excavated kiln had survived to a height of $60 \mathrm{~cm}$ on one side; there were traces of lime mortar on the exterior side. Because of the presence of the remains of wooden posts, Landsfeld was of the opinion that there could have been wooden shelves in the wall of the kiln, where the raw pots were placed to dry before firing. Two other spaces were connected to the furnace; they were described by the archaeologist as a drying oven and "fore-furnace". The kiln had a capacity of around 300 ceramic objects. ${ }^{4}$

They could generally reach a temperature in it of around $950-1000{ }^{\circ} \mathrm{C}$ that was suitable for the faience technique. The glaze containing tin-lead oxide melted at around 1000 ${ }^{\circ} \mathrm{C}$, and formed a shiny, opaque white coating (RADVÁNYI - RÉTI 2011: 25). The temperature inside kilns of this type was uneven, so it was very important where pots were placed in the firing chamber. It was also important to load the kiln with the right number of vessels of all types; otherwise the results of firing in an unevenly loaded kiln could be unpredictable. The firing temperature in the kiln could be controlled to a certain extent and directed even after heating by moving the glowing coals in the firebox to the right place and by creating a draught with the help of openings in the vaulted roof of the firing chamber.

Direct evidence of the former pottery kiln was found in the excavated squares in the western side of the site: bricks forming part of the kiln (two fully intact pieces) and numerous smaller brick fragments. They were originally red but had become brown from the heat and were vitrified by the concentrated heat on the surface facing the firing chamber. Blue glaze could be seen on one brick and the other had traces of thick turquoise glaze dribble. (Fig. 10) The latter find is of special interest, because to date only a few Haban vessels with glaze of this colour are known.

${ }^{4}$ After Landsfeld, BunTa 1973: 31. 
The most characteristic and largest number of finds that could be linked to the pottery kiln are the firing slabs with parallel ridges of different depth and width. One of the functions of these slabs was to separate the firing chamber from the kiln's firebox. None of the slabs were entirely intact and it was not possible to fit together a whole slab from the fragments, but in a few cases fragments could be fitted together to determine the width or the length. It was found that the firing slabs in Sárospatak were rectangular and on the average $16 \mathrm{~cm}$ long and $11 \mathrm{~cm}$ wide. The slabs differed in the height of the edge of the ribs and the width of the grooves between the ribs. It would appear that, like the kiln bricks and the glaze crucibles, these firing slabs were not made of any special, heat-resistant clay. The broken surface of the less used pieces seemed to indicate that they were made of the same clay fired to a brick red colour - although containing more grit - used for the vessels and stove tiles. The function of the ribs on the surface of the slabs was to catch the molten glaze when the vessel was fired. More than half of the firing slab fragments found had visible glaze dribbles: most often these were traditional lead glaze in various shades of green, but a few examples of white tin glaze and blue glaze also occurred. We also found cases where the entire bottom of the pot was pressed and burnt into the firing slab beneath it. In this case it is probably broken fragments of the kiln tripods that can be observed on the ribs. The firing slabs were worn out after a certain number of firings and so had to be continuously replaced. This partly explains why they occurred in such large numbers at our site: judging by the fragments that belonged to different pieces, at least 80 such slabs were unearthed. Although the ribbed firing slabs do not figure among the published material from the Moravian settlements, they occur among the unpublished assemblages from practically all the pottery centres there. ${ }^{5}$

Fragments showing the full profile of crucibles used to combine glaze materials, for frits found in the territory of the Haban settlement can be interpreted as six separate units. The crucibles can also be divided into two groups on the basis of size and form. Among the crucibles made of rougher-grained clay, generally coloured dark brown or grey from the strong heat and in a number of cases vitrified at the base, one group comprises pieces in the shape of small bowls $4.5 \mathrm{~cm}$ high, ending in a rounded edge widening like a funnel at the side. Crucibles $7-8 \mathrm{~cm}$ high with a larger volume can be grouped in the second category. The side of these crucibles widens, then from around the middle continues perpendicularly and ends in a simple, rounded edge. In the interior of one piece, remains of a substance congealed into a hard mass from finer particles and on the outer surface a thicker white tin glaze dribble can be observed. This same fragment is particularly noteworthy because the imprint of the ribbed firing slab can be clearly seen burnt into the bottom. There are a number of crucibles on which the remains of a frothy white substance can be found around the edge. Heřman Landsfeld (LANDSFeld s.d. 9; Fig. 3) published a piece from the Ostrožská Nová Ves site and Jiří Pajer (PAJER 2006: 121; Fig. 2) published similar pieces from Vacenovice that can be regarded as the exact analogy of the smaller crucibles from Sárospatak.

When placing plates in the kiln, firing tripods were placed between each piece to prevent them from touching during firing. Although we did not find any tripods in the

\footnotetext{
${ }^{5}$ Oral communication by Jiří Pajer.
} 
material excavated so far in Sárospatak, we can perhaps identify the traces of a tripod on one of the ribbed firing slabs, and the fragment of a blue-glazed plate that can be identified as a waster quite clearly bears the mark of a tripod. The saggars that were also used in the firing of glazed bowls serve a similar function to the tripod. The saggars are large vessel-like, unglazed cylinders, with holes in their sides. Several of these were arranged on top of each other in columns. Thin ceramic rods were passed through the holes to secure the bowls placed inside the saggars. Piccolpasso describes them as similar to the tripods and also included a drawing illustrating the saggars. Such an object is not known among the archaeological assemblages in Moravia, but a number of fragments that can be identified as saggars was found in Sárospatak. Four fragments, two of which fit together along the breakage surface, belong to the same saggar. Semicircular openings are placed at regular intervals, $40 \mathrm{~mm}$ apart, in the perpendicular sides that are fragmentary, so the original height is unknown. The bottom of the fragments is strongly burnt, almost vitrified. Numerous tiny white tin glaze spots and one blue glaze spot can be observed on the inner side of the fragments.

When making vessels with the faience technique, decorations were applied after the first firing, directly onto the ceramic surface covered with raw glaze, using a brush, feather or trailing container. In the case of lead-glazed vessels we can identify only the decorations applied by trailing. The trailing container is a pear-shaped hollow body made of clay and fired. The engobe or glaze was poured into the upper part, and flowed out through a long tube of a thickness corresponding to the desired pattern. As a result, the decorative motifs gave a plastic impression. Among the Sárospatak finds are several fragments of an object that can be identified from its shape as very probably a trailing container. A bubbly white tin glaze coating can be observed on the exterior of the orange-red ceramic body. Remains of white tin glaze can also be seen on the $6 \mathrm{~mm}$ mouth and around the outside edge of the container. It was probably used to apply white tin glaze decoration to ceramics with a blue ground. We do not know of any trailing container among the Moravian archaeological finds.

The Haban communities strove for self-sufficiency; they also made dishes for their own use. Although at first they may have made more decorative pieces for their own use, this was strictly forbidden by their later rules. According to a code of rules dated $11 \mathrm{De}-$ cember 1612: "Our people shall hand in all bone white, blue and other similar vessels with pewter fittings. Whatever was intended for sale and a source of money income shall be given to the potter, the remainder that are old and worn shall be used for their needs. The potters shall no longer make such costly vessels (that serve pomp much more than need) for themselves, their wives, friends and others among them. As it was in the past, they shall make for our people common black-yellow, green-coloured or plain earthenware dishes. If our predecessors were satisfied with them (when glaze was half as expensive as it is now), then we can be too." (KATONA 2001: 50-151)

The excavations in the Haban colony site yielded large quantities of lead-glazed ceramics that can definitely be interpreted as wasters or semi-finished products that differ strikingly in form and in the decoration technique used from the known $17^{\text {th }}$ century pottery in the region of North-eastern Hungary. The Hungarian literature pays almost no attention to the "traditional" pottery products, the lead-glazed vessels that can be linked to 
the Habans. One obvious explanation for this is that such pieces have not been preserved in public or private collections, and although in theory their occurrence can be assumed in the material from Early Modern age sites (castles, towns, manor houses), it is very difficult to identify them in the incomplete archaeological assemblages. Of course, it is also open to question whether pottery that can be identified with the type found in the Sárospatak excavation and used by the Habans in their own households appeared on the market at all. The assemblage from Strachotín, one of the most important Moravian settlements, and published in detail was of key importance in helping identify the varied ceramics that can be classified in this category. According to Jiří Pajer, the leader of the dig, the bulk of the ceramic finds here were the objects that the Habans used in their own households. A substantial quantity of ceramic objects that can be classified here were also found in the Haban settlement at Kobylí. On the basis of finds from the two sites, it was possible to identify not only the pots used in the kitchen for baking and cooking but also the objects used at the communal meals, and other ceramic objects of everyday use. Practically all the vessel types known from the two Moravian settlements cited above can also be found in the Sárospatak assemblage. (Fig. 6).

Ceramics decorated with trailing form one of the largest groups in the Haban colony assemblage. With the exception of four objects that can be identified as chamber pots, all of the objects in this group are plates. This ceramic material appears to differ from the finds known from Early Modern sites in Hungary, not only in form and decoration but in certain respects also in production technique. It is generally characteristic of trailed ceramics in this period that the surface of the vessels to be decorated was covered with white or red engobe, then the pattern trailed on the engobe. On vessels with a light ground colour, the contour lines were brown or dark brown, and where the ground colour was dark, they were white. In the case of a light ground, the contoured patterns were filled in with green and red, while on dark ground vessels, green or white was used. The decorated vessels were fired, then coated with a colourless lead glaze and fired again (ToMKA 2005: 37). In Sárospatak the trailed ceramics had a body fired to a brick-red colour. In the overwhelming majority of cases, the decorative motifs on the interior of the plates were applied directly to the clay by trailing white engobe, while the exterior was covered with a continuous layer of white engobe. After the first firing, the inside was coated with a colourless lead glaze and the outside with a green, or more rarely a yellow lead glaze, then fired again. After the second firing the white engobe decoration covered with a colourless lead glaze became yellow, while the red pottery surface without engobe acquired a reddish-brown shade from the colourless lead glaze. There are examples, although only a few, of vessels made in a different way from the above. In one such case, the inner sides of the plates were covered with white engobe and the motifs applied to this with red slip, then after coating with colourless lead glaze the vessel was fired. In the case of a half-finished plate without glaze, a running dog band applied with white engobe can be seen in a band painted black on the red body and framed with white engobe. (Fig. 1)

The plates made with the trailing technique can be divided into two main groups based on form. The first group comprises plates with rims, in which the well of the plate and the rim are divided by a sharp angle, while the second group contains bowls with deeper wells and no rim. The two types occurred at our site in the ratio of 1:10, in favour 
of the latter type, but this figure is not entirely precise because in the case of a few bottom fragments, it could not be determined whether they should be classified into the first or second category. The shapes of the plates with rim can be observed in full profile on an example assembled from its fragments and the losses filled in. At roughly the middle of its height there is a break in the rounded side from which the body rises at a flatter angle in a broad rim, then ends in a perpendicular edge that is sharply distinct from the rim and in cases is profiled on the outside. This profile can also be seen in a semi-finished example, and parts of the shape can also be seen in fragments of a few other plates with rims. The rims of the plates with rims range from $22-33 \mathrm{~cm}$ in width. The pieces in the other group of bowls occurring at the site have larger edge diameters, deeper wells and no rims; they widen continuously towards the edge and have a profiled foot rim or more rarely a foot ring. The well of the bowl is perpendicular and ends in an edge band profiled on the outside, then in a small rounded edge inflected at an angle of 45 degrees. The diameter of edges in the group of deep bowls ranges from $28-38 \mathrm{~cm}$. The highest extreme value is found in three examples. (Fig. 9)

The decorative motifs composed of geometrical elements running around the plates display a quite uniform system. The compositions typically comprise three zones: geometrical patterns are used on the rim and around the well of the bowls, and a larger central motif is placed in the middle. The patterns occurring on the rim include running dog rows, rows of three leaves turned on their sides, slightly curved and crossed at the stems, and rows of two leaves turned on their sides, curved more strongly than in the previous example, crossed with short lines and curling back at the ends. On the well of bowls with rims, there are short curves in opposite directions combined with a wavy line, and a row of dots surrounded by parallel lines with an arch around them. The inflected edges of deep bowls sometimes have a wavy line around them, and a wavy line or horizontal double line on the edge zone. There are also examples where the horizontal line ends and is continued in a row of dots. The decoration of the well consists of variations of the above elements. In some cases the entire well zone is decorated with wavy lines separated by parallel lines, a row of arches combined with points also appears and in other cases concentric circles are placed in the hollows of the row of curves.

It is more difficult to reconstruct the central decoration in the bottom well of the plates from the fragments. Besides the central rosette motif in the plate with rim that has been reconstructed with the losses filled in, a symmetrical, five-stemmed floral motif appears at the bottom of another plate. There are two examples of a geometrically constructed star motif, in one case combined with spots. The stock of motifs on the Sárospatak plates decorated by trailing shows a close relationship to the material of Kobilí and Strachotin from among the Moravian settlements, with the difference that the plates there are often provided with a year. So far no dated fragment has been discovered among the Sárospatak material.

A striking difference compared to the plates of the Early Modern age is that the Haban plates are characterised by the absence of a suspension loop. These plates must be interpreted not as ceramic objects decorating rooms but as the dishes in everyday use by the inhabitants of the settlement. The larger bowls are generally burnt on the outside and 
inside surfaces, smudged in some cases almost to the extent of obliterating the pattern. These bowls were probably used in the kitchen for baking, while the bowls that have no trace of burning were presumably used to serve food. One bowl has many scratches of different size on the bottom and the well, probably made from the use of a knife when eating the food. It is of particular note that many examples of large bowls were successfully identified, fragments that could be linked to the classic plate form often occurring among vessels from the second half of the $17^{\text {th }}$ century were not found at all among the vessels the Habans made for their own use - although there are fragments of this type of vessel with white tin glaze and blue glaze among the finds.

Within lead-glazed ceramics decorated with trailing the chamber pots represent a special type that is rare also in the Moravian settlements. (Fig. 7) A total of four such objects that can be divided into two subtypes occur in our finds, one of which has been successfully restored with the replacement of losses, the other three could be reconstructed from fragments only in sketches. One subtype contains chamber pots with a slightly slimmer body narrowing conically towards the edge, while those in the other group have a squatter form and almost perpendicular sides. All the Sárospatak chamber pots have a sharply outcurving edge with two handles; they are covered with a green glaze over white engobe on the exterior and a colourless glaze on the interior and decorated with trailing. Geometrical patterns similar to the motifs on the bowls appear on the edge and the upper third of the interior: running dog row, row of dots, wavy lines around the object, arches, horizontal lines, two curved leaves lying on their side and interlinked. The known analogies for this type of vessel from Moravia and Slovakia, namely one from Kosolna (Košolna, Slovakia), and two published from Strachotin, all have a plain monochrome glaze and are undecorated.

The very fragmentary ceramic finds appearing over a larger area, not linked to intrusion, concentrated in the NW corner of unit II of the 2012 excavations, can be identified on the basis of their characteristics as pieces of pots thrown out as wasters after firing. This identification is supported by the lengthwise cracks in the handles of vessels, the deformation that can be observed in a few cases, and the fact that the fragments are uniformly without glaze. One group of the finds - roughly two-thirds of the total - is completely covered with white engobe on the exterior while the remainder were found without a layer of engobe.

The fact that a great part of the assemblage consists of very small fragments, only a few centimetres in length, is an obstacle to their more thorough evaluation. A conclusion can be drawn regarding the number of vessels found here from the handles, given that apart from a few uncertain exceptions classified here, they were all intended for the storage of fluids. On the basis of the handles that can be associated with certainty to particular examples, this assemblage contains fragments of at least 50 vessels that can be classified into three main types and in cases their variants either in size or in minor details of shape. All types are characterised by a body fired to a brick red colour. They generally have thin thrown sides: close to the bottom 4-5 $\mathrm{mm}$ thick and in the middle part of the vessel 2-3 mm. The first group, formed on the basis of typology, contains the smallest number of pieces identified as egg-shaped jugs with a profiled base, a narrow mouth for drinking and flanged handle. (Fig. 3) The jugs or their fragments in this group have a grooved handle and the neck of the vessel has been pierced above the place where the handle is attached. All of the objects in this group were covered with a layer of white engobe. The second type contains globular vessels with a rim at the foot and a neck extending 
$5 \mathrm{~cm}$ up from the body, provided with a concave filter insert widening from the middle up, the mouth lip pressed into a lobed shape. (Fig. 2) This type occurs in our material in both smooth and fluted forms. The body of the latter vessels has been divided into five or six segments from the neck to the foot using the edge of a wooden knife. The segments spiral upwards, giving the impression that the whole body of the vessel is twisted. The handle of jugs in this group has an oval cross-section. Fragments of this group occur in larger quantity. The white engobe layer can be seen on the majority but a few examples without engobe can be found among them. The third type category comprises egg-shaped vessels with a shorter perpendicular neck, oval crosssectioned handle and wide, round mouth. (Fig. 4) Two of the three types in the group of finds are quite rare, but not entirely unknown in Haban ware. There is only one published example of a jug with a narrow mouth for drinking and flanged handle in a collection. The blue-glazed piece in the collection of the Museum of Applied Arts that can be dated to 1695 differs in parts of its shape from those found in Sárospatak; it has a differently shaped neck and the body is bulbous (RADVÁNYI - RÉTI 2011: Fig. 329). Among the vessels in the region in the Early Modern age intended for the storage of fluids, glazed jugs with flanged handle were popular types, although their use was probably most widespread in the second half of the $16^{\text {th }}$ century. ${ }^{6}$ According to the evidence of dated examples in collections, the type of vessel with a longer neck, pinched mouth, closed with a strainer below the mouth part, appeared at the end of the $17^{\text {th }}$ century. Water jugs with narrow mouths are relatively rare in the known Haban material. It is the hypothesis of the research to date that these unusually shaped jugs, showing a close relationship to the proportions of Turkish copper vessels - like the jugs with flanged handles, entirely unknown in the material from Haban settlements in Moravia - could have been made in the settlement in Alvinc in Transylvania, a territory that was in close contact with the Turks. ${ }^{7}$ However, their occurrence in our finds shows that these jugs were also made by the Haban potters in Sárospatak and it is possible that this type may have been present already from the mid-17 th century. In one of his letters, Tamás Debreczeni mentions "jugs for sour water" made by the Habans, which could perhaps have been identical with the "jug with strainer, for water" listed in the 1639 inventory of the Sárospatak castle. ${ }^{8}$ The screen could refer to the filter in the neck of the vessel used for fluids. The vessels in the third group can be regarded as one of the most typical Haban vessel forms. The earliest Moravian pieces were made with a large, rounded belly and a short neck, then in the mid-1 $17^{\text {th }}$ century a more elongated, oval form appeared. These vessels, known in various sizes, were probably used to store wine (RADVÁNYI - RÉTI 2011: 27). It would appear from this assemblage that the Habans in Sárospatak, like their brethren in Alvinc, also made vessels differing in shape from their traditional ceramic art.

Although the very small area of the Sárospatak Haban colony excavated so far and the finds unearthed there do not yet allow a comprehensive evaluation, we can already venture a few seemingly general findings. The Haban colony in Sárospatak functioned under differ-

\footnotetext{
${ }^{6}$ Tомка 2005: 101-102, 114. The examples published from Ónod, Szendrö, and Mohi all have band handles and a more prominent neck than the jugs from Sárospatak.

${ }^{7}$ The known examples that can be classified into this type entered the Museum of Applied Arts in the late $19^{\text {th }}$ and early $20^{\text {th }}$ centuries from the Lázár, Sigerius and Bálint collections. RADVÁNYI - RÉTI 2011: 27; and Figs. 231; 331-332; 334.

${ }^{8}$ Extract from a latter by Tamás Debreczeni dated 5 October 1647. Cited in: DéTshy 1972: 132. The "sour water" (savanyú viz) probably refers to medicinal water; in 1629 an Anabaptist doctor treated Gábor Bethlen's increasingly grave illness with a course of sour water, mineral water from Száldobos. KatONA 2001: 32.
} 
ent circumstances from those that must have been characteristic of the Moravian colonies. In Moravia, in a relatively small area, a dense network of Anabaptist colonies was formed, some of them with large numbers of members, in continuous contact with each other. Not only must there have been an intensive flow of raw materials and production know-how; there was probably also a definite division of labour among the different crafts settlements, including even the distribution of customers' requirements. The Haban community settled in Sárospatak found itself in a state of isolation, where their craftsmen had to produce products of the highest possible quality under the changed circumstances and possibilities. This must have required a kind of compromise and a certain degree of technological change in the area of pottery too. While the Moravian faience pieces were made exclusively from clay that fired to a yellowish-white, the picture is not so clear from the tin-glazed fragments discovered so far in Sárospatak. It is worth noting that among the white tin-glazed faience from Sárospatak, we also find vessels made from clay that was fired to a brick red colour, generally characteristic of traditional pottery and in particular of the "Patak pottery", while such pieces are unknown among the Moravian faience. One obvious explanation for this could be that when there was no clay of the kind ideal for making faience that could be quarried in the immediate vicinity, they were obliged to use whatever clay could be found. At the same time, there are also signs of technological constancy arising from their insistence on continuing workshop traditions.

Because of the spatial limitations of the excavation, we cannot obtain a full picture of the products produced by the Haban potters in Sárospatak together with the technology used, but the finds unearthed offer a good cross-section of a segment of Haban pottery almost entirely unknown in Hungarian research: lead-glazed ceramic ware produced largely for their own community. Within the ceramic material from the Haban colony in Sárospatak we can observe various vessel types of different origin (German, Italian), some of which have analogies - or in a few cases even completely identical pieces - in the finds from Haban colonies in Moravia and Slovakia. Besides the persistent forms and decorative features developed decades earlier, there are also new forms entirely unknown in the Moravian material. This is the case of the oriental-looking jug with a fluted, flattened globular shape and a longer neck with a strainer, found among the wasters in Sárospatak. (Fig. 2, Fig. 3) The production of one of the most popular vessels for the storage of fluids in the Early Modern age, also occurring at the excavation site as kiln waste, the jug with a narrow mouth for drinking and flanged handle, may also be evidence of adaptation to demands arising in the wider environment.

On the basis of the indirect evidence unearthed there is hope that we may also be able to document the remains of the pottery kiln, and further excavation could also clarify many questions concerning the internal structure and topography of the colony site. Parallel with this, it is important to systematically collect, classify typologically and examine archeometrically the Haban ceramic finds occurring in growing numbers from digs in recent years, in the sites of major importance in the region. ${ }^{9}$ It is only from all these together that we can hope to make a substantive exploration of the connections between the Haban pottery workshop in Sárospatak, as production centre, and the places where the products occur and were used.

\footnotetext{
${ }^{9}$ In the course of the ongoing excavation of Regéc castle begun in 1999, in addition to a substantial quantity of Haban ceramics and stove tiles, a group of floor tiles has been found that can be linked to the Habans and is unique in Hungary. A considerable quantity of varied Haban ceramics and stove tiles have also come to light in the excavations of the Tokaj castle ongoing since 2007. Oral communications by Mihály Giber and Miklós Makoldi.
} 


\section{LITERATURE}

\section{AFR}

MNM Magyar Nemzeti Múzeum [Hungarian National Museum]

MOL U et C . Magyar Országos Levéltár Urbaria et Conscriptiones [Hungarian National Archive Urbaria et Conscriptiones]

Bunta Magda

1973: Az erdélyi habán kerámia [Transylvanian Haban Ceramics]. Bucharest, Kriterion.

DÉTshy Mihály

1972: Adalékok a sárospataki újkeresztények (habánok) történetéhez [On the History of the Anabaptists (Habans) in Sárospatak]. A miskolci Herman Ottó Múzeum Évkönyve XI, 123-144.

KATONA Imre

1974: A habán kerámia Magyarországon [Haban Ceramics in Hungary]. Budapest, Képzőmüvészeti Alap Kiadó.

2001: Habánok Magyarországon [Habans in Hungary]. Budapest, Gesta Kiadó.

Kovács Béla

1986: $\quad$ Habán $=$ Anabaptisa $=$ Újkeresztény $\neq$ Neochristianus $[$ Haban $=$ Anabaptist - Neochristian $]$ AGRIA XX, 91-98.

LANDSFELD, Heřman

s.d.: Habánská keramika a Lidová Hrnčina. Strážnice - Zámek.

PAJER, Jiř́

2006: Studie o Novokřtěncich. Strážnice, Etnos.

2007: Archaeological Excavation of Anabaptist Ceramics in Moravia. In: Studies in Post-Medieval Archaeology 2. Prague, Archaia.

2011: Anabaptist Faience from Moravia 1593-1620. Catalogue of documents from institutional and private collections. Strážnice, Etnos.

RADVÁNYi Diána - RÉTI László

2011: A habánok kerámiamüvészete [The Ceramic Art of the Habans]. Budapest, Novella Kiadó.

Ridovics Anna

2008: A habán kerámia a 17. században [Haban Ceramics in the $17^{\text {th }}$ Century]. In: Mıкó, Árpád - Verö, Mari (eds): Mátyás király öröksége. Késö reneszánsz müvészet Magyarországon. (16-17. század [Legacy of King Matthias. Lata Reneissance Art in Hungary (16 $6^{\text {th }}-17^{\text {th }}$ Century]). Budapest, Magyar Nemzeti Galéria. 86-97.

RoMÁn János

1955: Sárospataki kerámia [Sárospatak Pottery]. Budapest, Képzőmüvészeti Alap Kiadóváll.

1959: A habánok Sárospatakon [The Habans in Sárospatak]. A Sárospataki Rákóczi Múzeum Füzetei 17. Sárospatak.

1965: Zemplén megye XVI-XVII. századi iparának szakmái és mesterségei, különös tekintettel Hegyaljára $\left[16^{\text {th }}-17^{\text {th }}\right.$ Century Occupations and Crafts in Zemplén County, with Particular Regard to Hegyalja]. In: Borsodi Történelmi Évkönyv I. 9-91.

TомKa Gábor

2005: Északkelet-Magyarország kora újkori kerámiája [Ceramics of the Early Modern Age in North-eastern Hungary]. Doctoral dissertation. Manuscript. Budapest, 2005. 


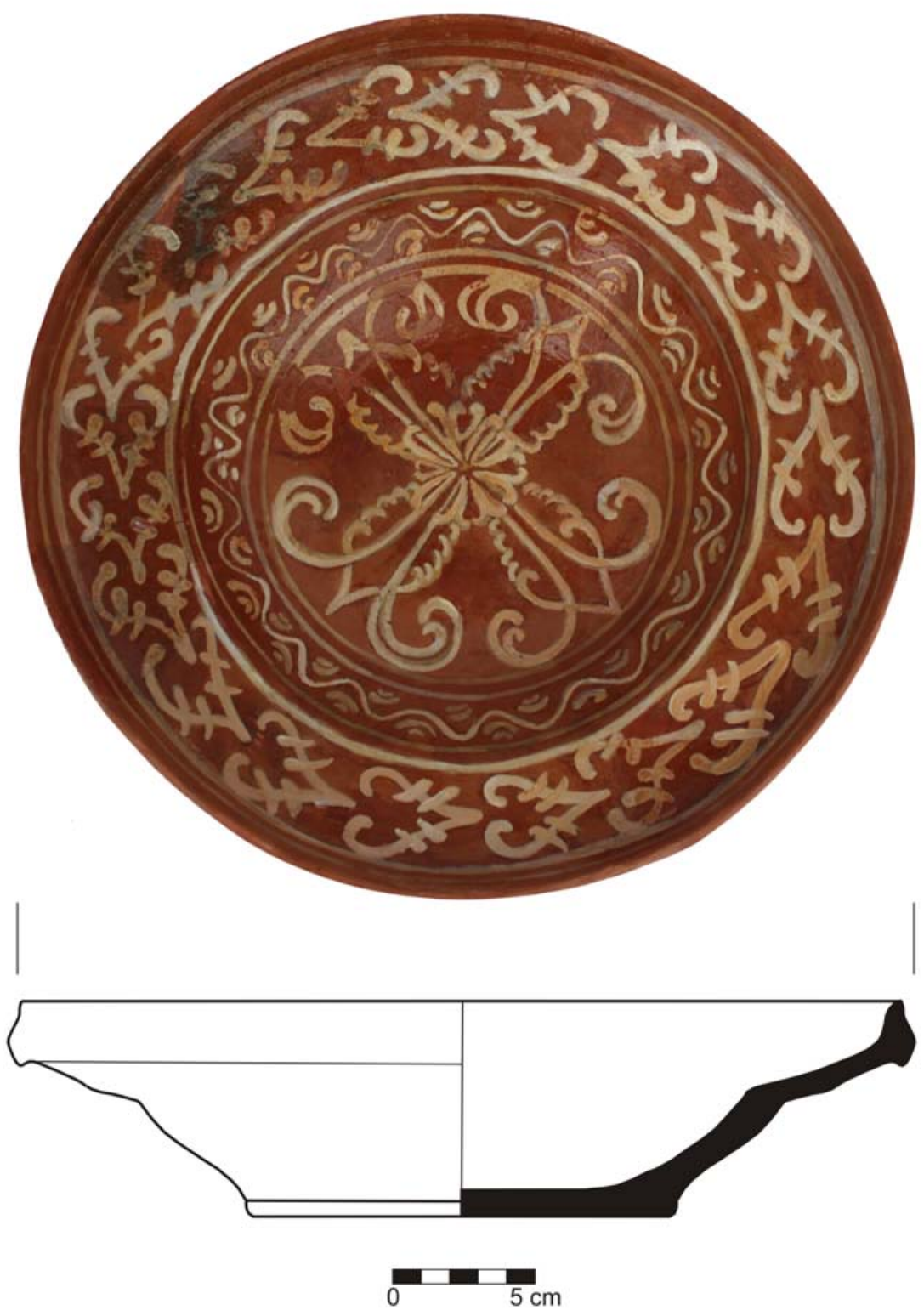

Fig. 1. Trailed plate with rim (sketch: Zsófia Bocsi; photo: Máté Szilágyi) 

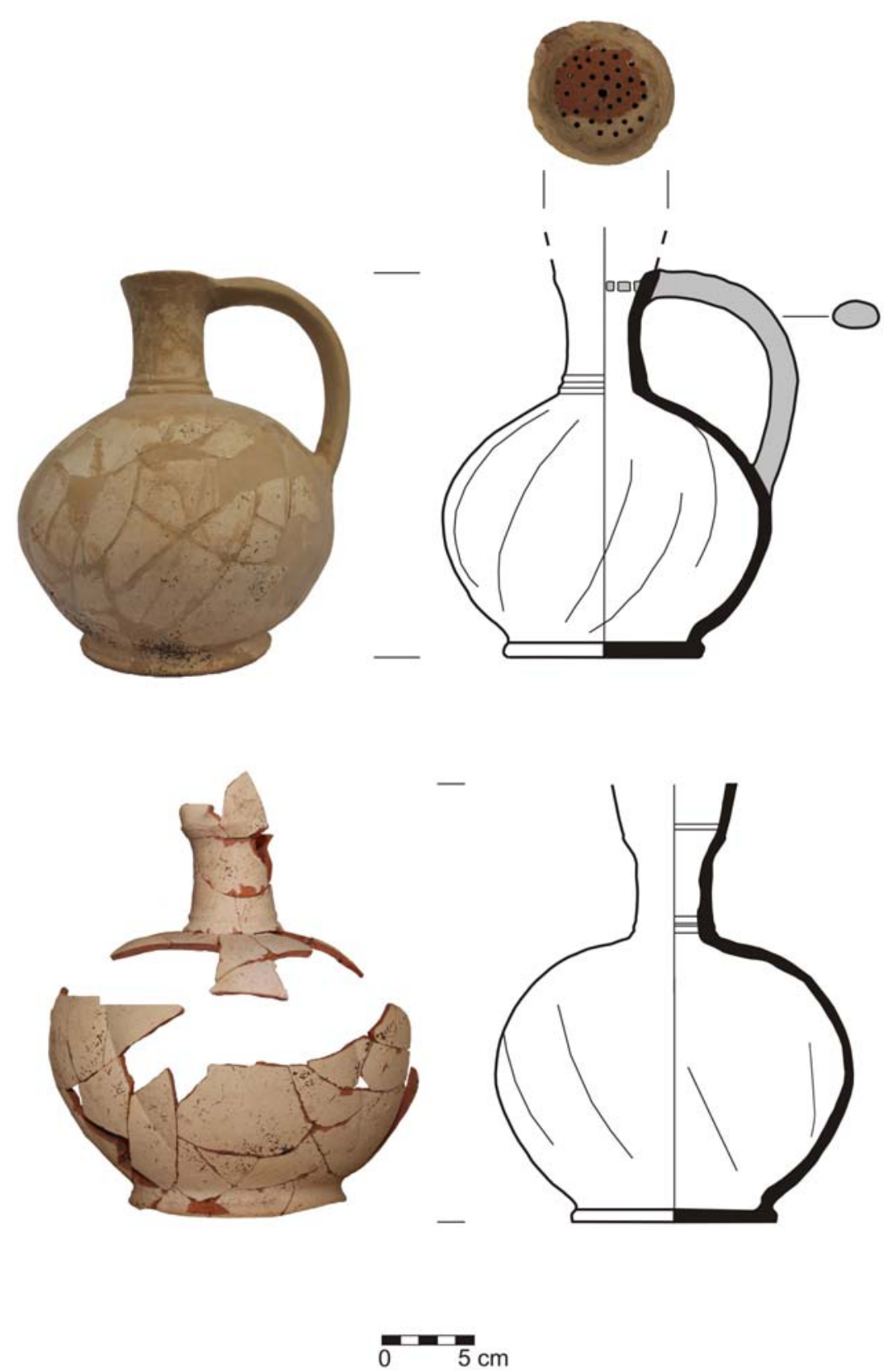

Fig. 2. Jugs with strainers found among kiln wasters (sketch: Zsófia Bocsi; photo: Máté Szilágyi) 

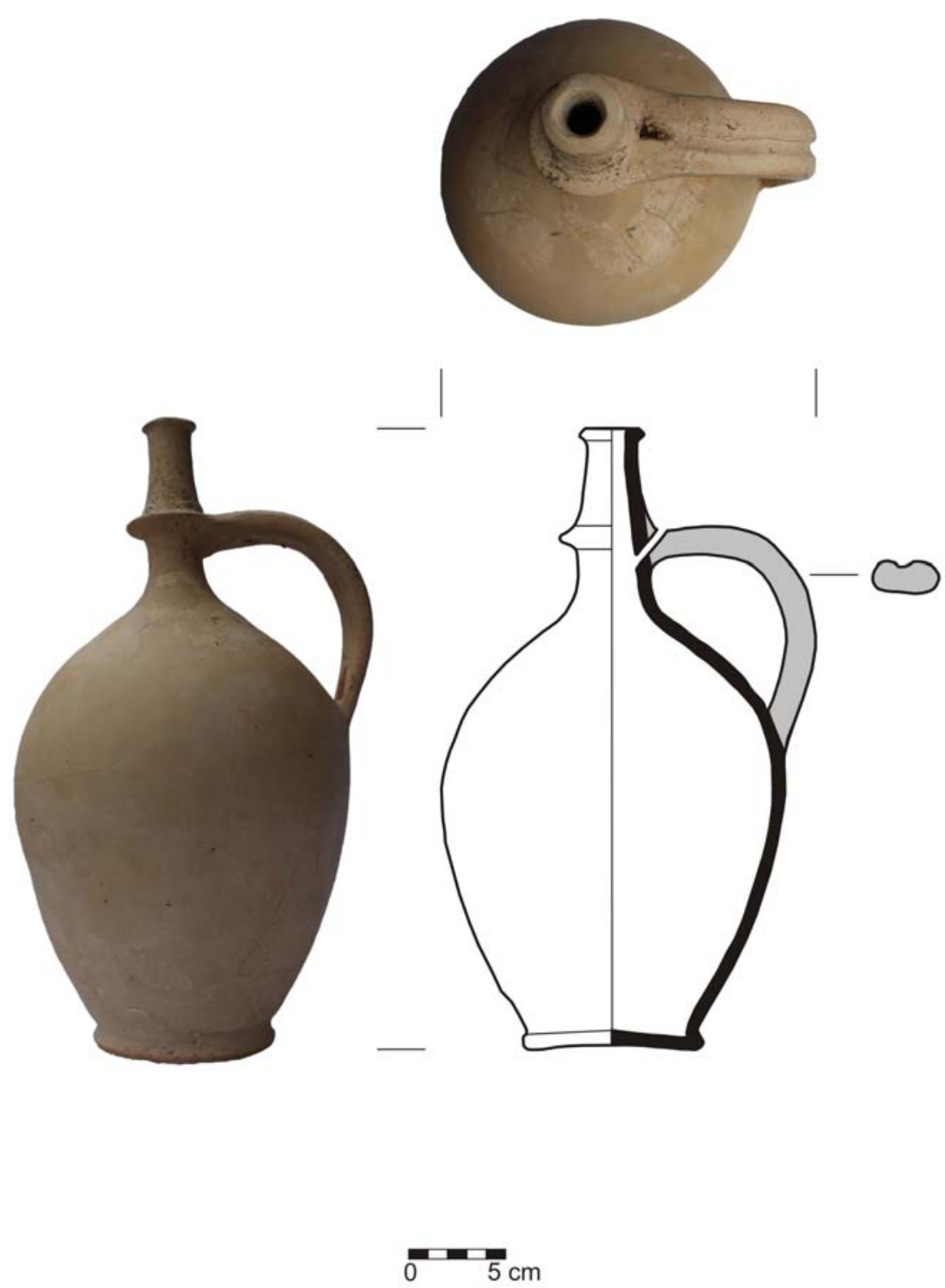

Fig. 3. Jug with flanged handle found among kiln wasters (sketch: Zsófia Bocsi; photo: Máté Szilágyi) 

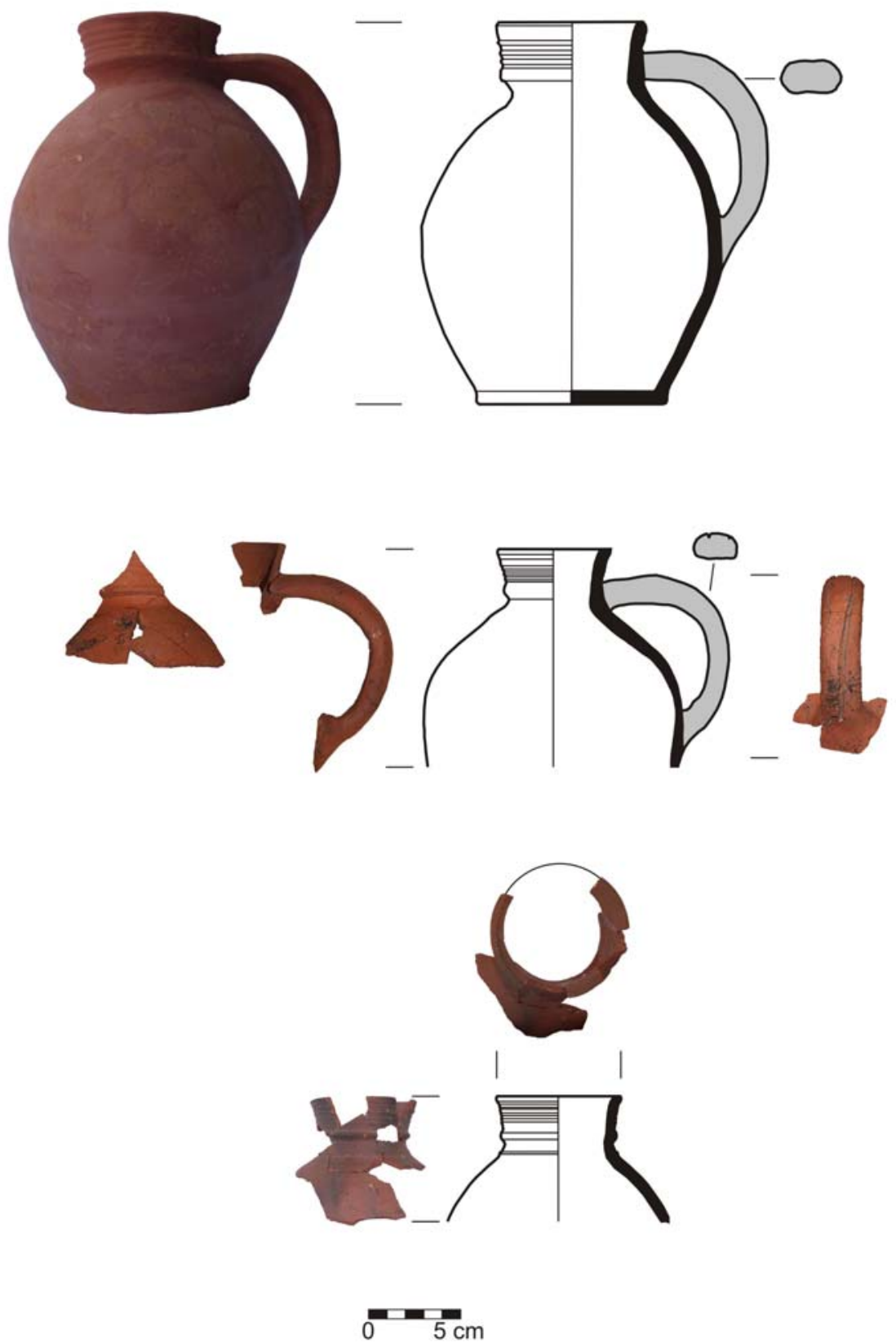

Fig. 4. Water container jug (sketch: Zsófia Bocsi; photo: Máté Szilágyi) 


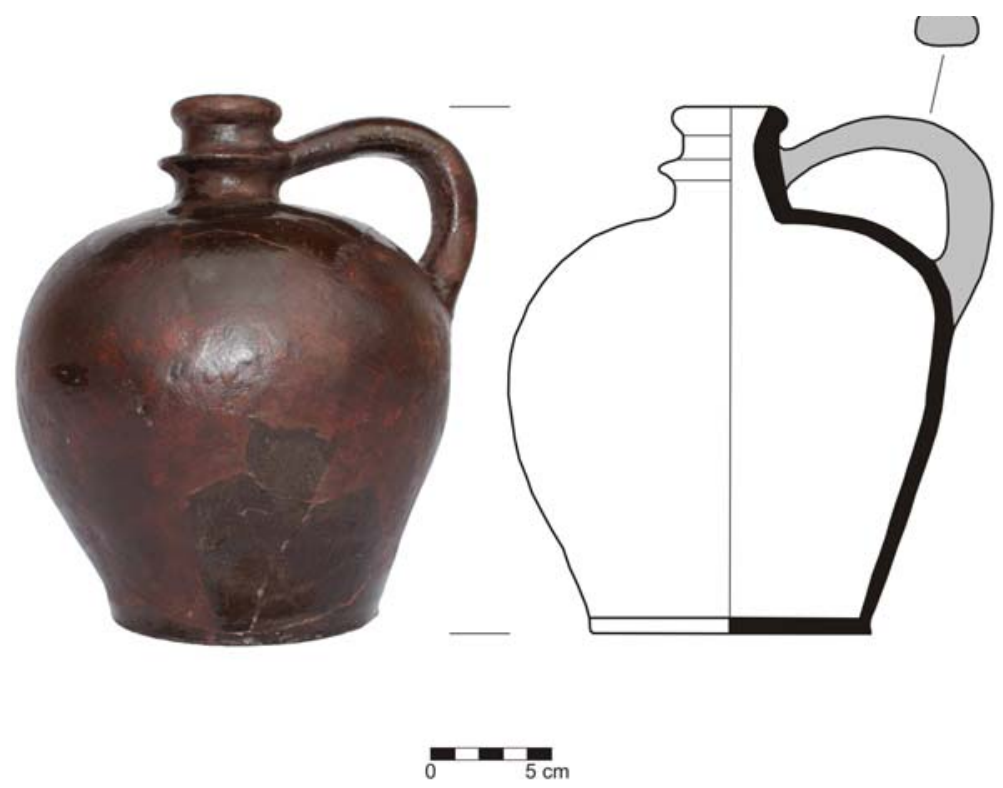

Fig. 5. Brown-glazed jug (sketch: Zsófia Bocsi; photo: Máté Szilágyi)
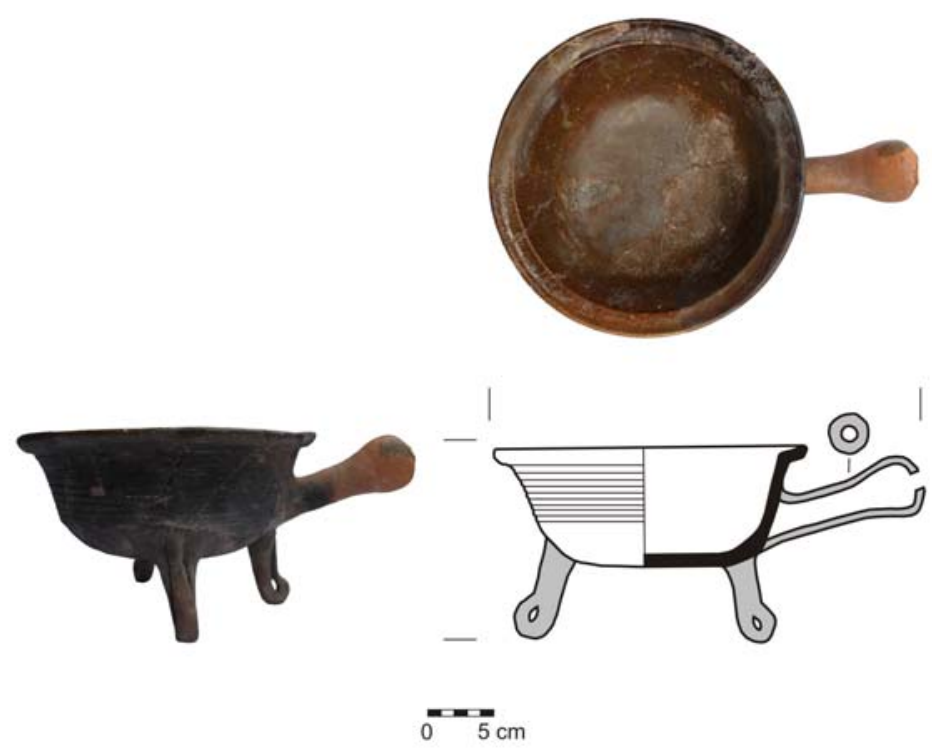

Fig. 6. Cooking pot with handle (sketch: Zsófia Bocsi; photo: Máté Szilágyi) 


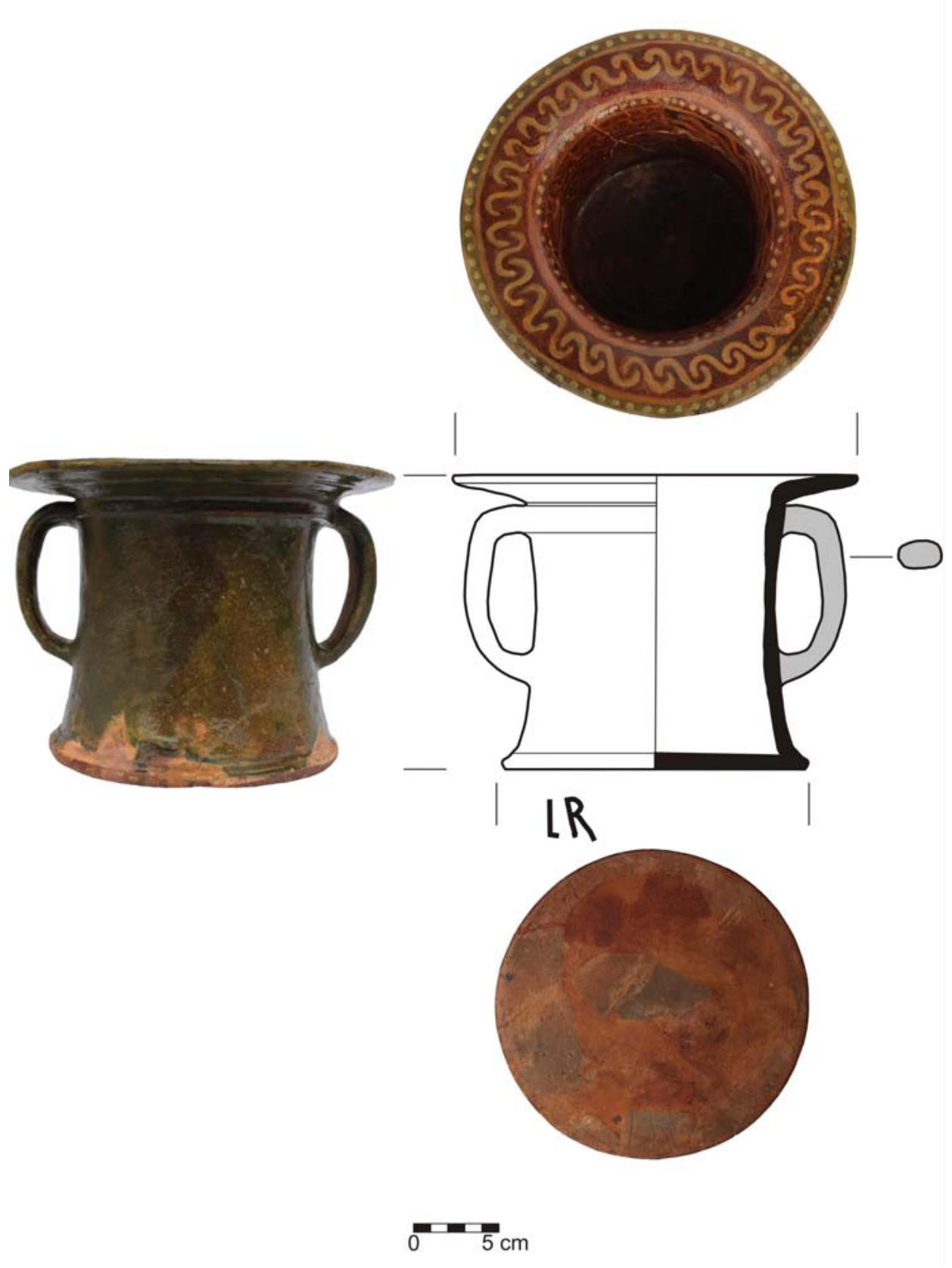

Fig. 7. Chamber pot (sketch: Zsófia Bocsi; photo: Máté Szilágyi) 

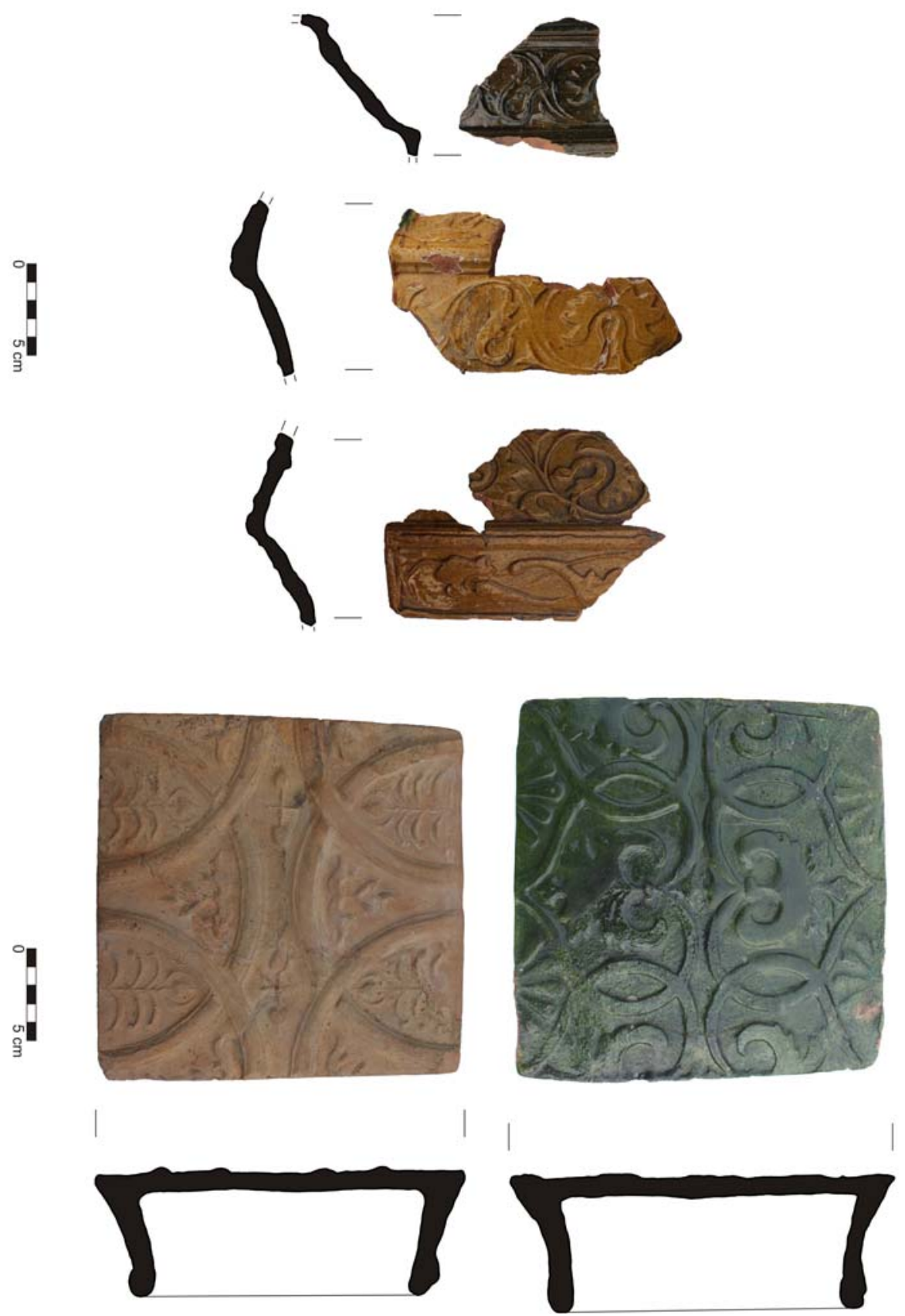

Fig. 8. Stove tiles (sketch: Zsófia Bocsi; photo: Máté Szilágyi) 

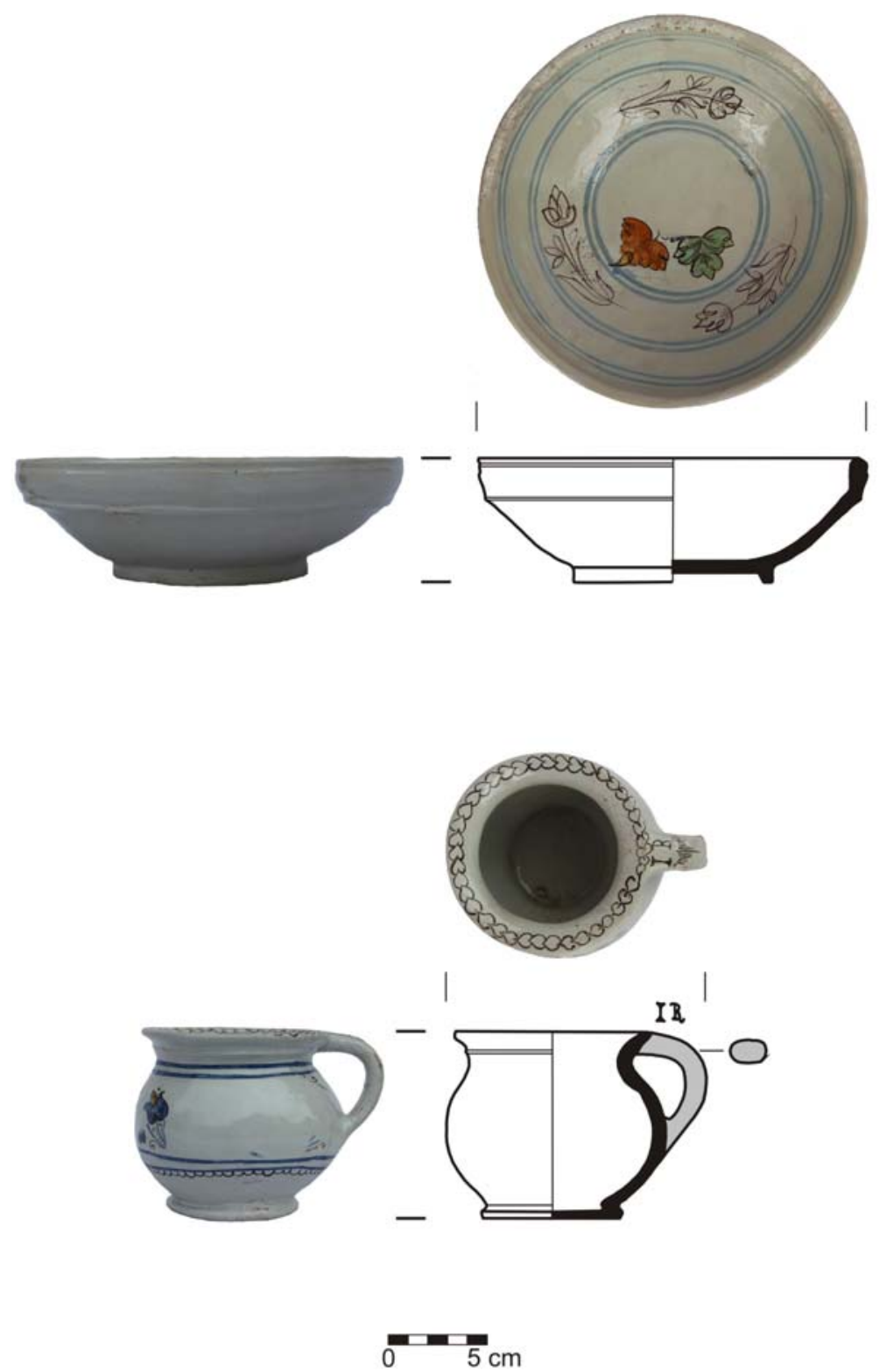

Fig. 9. White tin-glazed ceramics (sketch: Zsófia Bocsi; photo: Máté Szilágyi) 

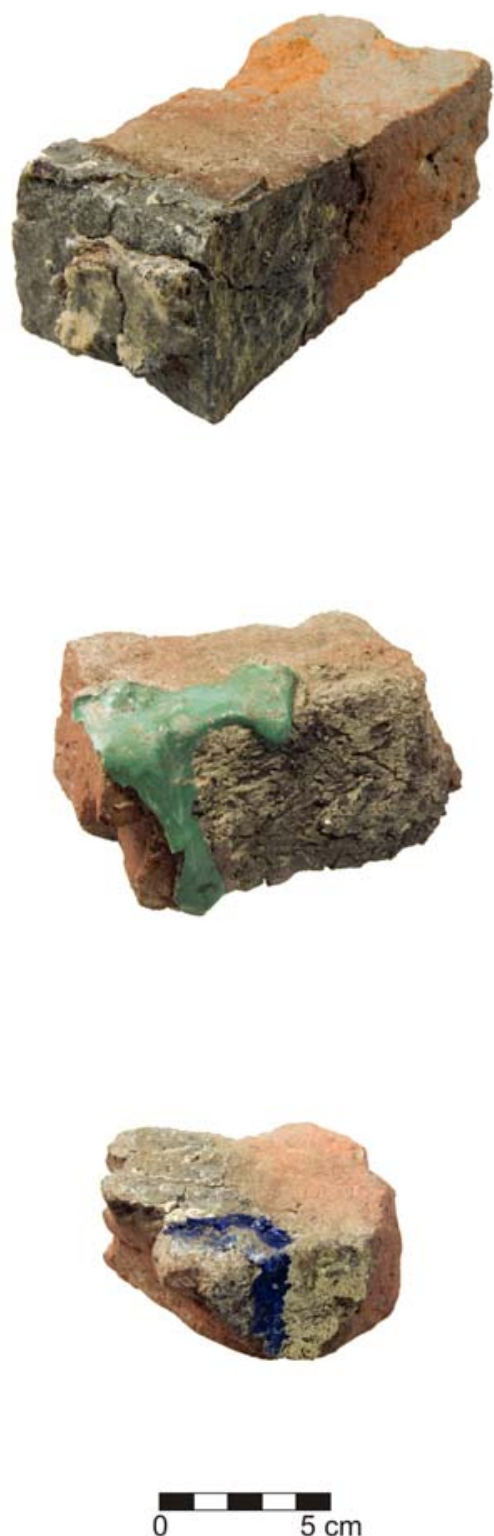

Fig. 10. Fragments of bricks that can be linked to the Haban pottery kiln (photo: László Váradi) 